\title{
Ética e ontologia em Lukács e o complexo social da educação
}

\author{
Mônica Mota Tassigny \\ Universidade de Fortaleza, Centro de Ciências Humanas
}

\section{Introdução}

Na década de 1970, surgem, no cenário educacional, críticas às visões estruturais-reprodutivistas da educação. A partir dos anos de 1980, colocou-se com mais ênfase o debate sobre as relações entre trabalho e educação no Brasil, sobretudo como crítica ao reducionismo econômico das várias matrizes da teoria do capital humano. A crítica evoluiu para a elaboração de uma concepção de formação escolar unitária e politécnica, cujo princípio educativo repousa no trabalho. ${ }^{1}$

Embora sejam contribuições inquestionáveis para a compreensão do fenômeno educativo na sociabilidade capitalista, ressente-se de uma discussão mais explícita sobre a dimensão ontológica do trabalho e

${ }^{1}$ Com relação à intensificação do debate educacional sobre a relação trabalho e educação e concepção politécnica, refiro-me, sobretudo, aos estudos, já bastante conhecidos, dos autores brasileiros: Lucília Machado, Tadeu Tomaz da Silva, Dermeval Saviani, Gaudêncio Frigotto, Celso Ferreti, entre outros. da educação; isso é, falta clareza à fundamentação dos elementos internos da essência, da natureza e da estrutura dinâmica da educação, tanto em sua relação com o trabalho quanto com a totalidade social.

Tudo isso obriga a situar em primeiro plano a dimensão ontológica da educação, ressaltando sua relação com o trabalho, não para limitar o trabalho a uma exagese ou reiteração das concepções atuais sobre a relação trabalho-educação, mas para devolvêlas às suas origens ontogenéticas, ressaltando-as como mediações fundamentais no processo de desenvolvimento do gênero humano.

Obedece, portanto, a uma preocupação comum deste trabalho colocar em relevo a perspectiva éticoontológica de Georg de Lukács, numa fundamentação do complexo social da educação. São essas, assim, aproximações da questão fundamental: com base em algumas das considerações ético-ontológicas de Lukács, discutir a natureza da relação educativa do homem com a realidade material e social.

A educação não se constituiu certamente como o tema central de Lukács. Porém, em seus fundamentos sobre a ética e a ontologia, a educação aí se 
encontra presente incontestavelmente. A partir daí, pôde-se analisar o complexo social da educação, bem como inferir a natureza e a especificidade da educação no conjunto da práxis humana.

\section{A relação ética e ontologia em Lukács}

A Ontologia do ser social de George Lukács (1981) foi concebida, inicialmente, como uma introdução a uma futura ética. Assim, as análises ali contidas sobre a ontogênese e a filogênese do indivíduo remetem, invariavelmente, à ética. Diferentemente das espécies animais, os indivíduos não são exemplares mudos da espécie, isto porque participam ativamente, com suas ações, no destino da totalidade do gênero humano. ${ }^{2}$

Para Lukács, as ações dos indivíduos singulares repercutem, sem cessar, na vida dos outros e, ao menos potencialmente, são capazes de influir na sociedade inteira e, no limite, no destino mesmo do gênero humano. A história humana é compreendida por Lukács como constantemente atravessada pela tensão entre dois pólos da sociedade: o gênero humano, como síntese e totalização das ações individuais, e as ações dos indivíduos em sua singularidade e particularidade histórica. Nesse particular, o autor pretendeu combater os principais erros de interpretação do marxismo sobre a história: tanto a visão puramente determinista, que considerava como absoluta a noção de lei histórica e os indivíduos como simples agentes dessa lei, quanto à concepção hegeliana de história, de tipo teleológica, produto das intenções da vontade humana.

Nesse quadro, a distinção entre o gênero humano em-si e o gênero humano para-si passa também a explicar a qualidade das ações dos indivíduos. Há aque-

${ }^{2}$ Em Lukács, o gênero humano é a síntese da individualidade e da generalidade da espécie humana. É o critério de referência do desenvolvimento humano, por isso a síntese do desenvolvimento da personalidade do indivíduo particular, situado historicamente, e do desenvolvimento da humanidade como um todo (Lukács, 1981, v. II**, p. 44-45). las ações que asseguram a conservação do status quo social (gênero humano em-si), em que o peso da heteronomia é particularmente forte; e aquelas ações que têm como objetivo uma auto-afirmação humana, ou o desenvolvimento de uma personalidade autêntica e livre (gênero humano para-si). Nessa distinção, a ação ética foi considerada por Lukács como momento privilegiado da práxis social, locus onde se realiza a autodeterminação do gênero humano para-si, livre e autônomo.

Na Ontologia, Lukács ainda elaborou uma verdadeira arquitetura da subjetividade (Tertulian, 1984, p. 136) para tornar inteligíveis as bases sócio-históricas da alienação. Nessa questão, característica do gênero humano em-si é a tendência de reduzir o indivíduo a sua própria individualidade. Já o gênero humano para-si aspira por uma personalidade livre e autêntica.

O pôr teleológico, ${ }^{3}$ a projeção, o momento da ideação que precede todo ato de trabalho é definido como o fenômeno originário da vida social, e é também decomposto em dois movimentos distintos: a objetivação e a exteriorização.

Ressaltando a articulação, assim como a possibilidade de divergência entre esses dois momentos no interior de um mesmo ato, o autor valoriza o espaço de autonomia da subjetividade em relação às exigências da reprodução social. Diante de uma realidade histórica particular, com os limites que ela impõe à capacidade de objetivação humana, as alternativas das reações subjetivas (a exteriorização da interioridade) podem ser muito amplas.

$$
\text { O campo da alienação se situa no "espaço interior" }
$$
do indivíduo como uma contradição vivida entre a aspiração pela autodeterminação da personalidade e a multiplicidade das suas qualidades e de suas atividades que visam à reprodução de um todo estranho. A distorção entre objetivação e exteriorização, entre o comportamento do indiví-

\footnotetext{
${ }^{3}$ Fim, objetivo de dada ação, telos da práxis social, intenção
} humana ou projeção final de uma dada ação, por isto principium movens de toda vida social. 
duo como agente da reprodução social e a auto-expressão de sua personalidade, traduz-se pelos bloqueios e pelos rechaçamentos (no caso de aceitação do status quo social) ou ao contrário, por atos de resistência e de oposição ativa.

(Tertulian, 1984, p. 151)

É por demais conhecido que, concordando com Marx, para Lukács o trabalho é concebido como categoria fundante do ser social; entretanto, para fins analíticos e diferentemente de Marx, ele o decompõe em dois momentos: objetivação e alienação, embora no ato real esses momentos sejam inseparáveis. Em relação à capacidade humana de objetivação, ou capacidade de alienação, Lukács destaca o sentido positivo da exteriorização (Entäusserung) como possibilidade humana de criação de objetos sociais, antes inexistentes na natureza. Contudo, nem todas as objetivações humanas desempenham papel positivo no desenvolvimento da personalidade e, em determinadas situações históricas, apresentam-se como verdadeiros obstáculos ao desenvolvimento humano.

Lukács (1981, v. II**, p. 559-560) denominou tais momentos negativos de estranhamento (Enfremdung). Na sociabilidade capitalista, o fenômeno do estranhamento aparece com uma amplitude jamais vista na história. Para o autor, a sociedade burguesa é síntese de relações sociais movidas predominantemente pela reprodução do capital. Criação humana, o capital passa a dominar a vida dos homens, em todas as instâncias da vida social, de forma que as ações humanas passam a estar prioritariamente atreladas às necessidades de valorização (acrescentar valor ao) do capital. Nesse particular, os indivíduos são postos como instrumentos de execução de uma posição teleológica geral que dá suporte à produção/reprodução da sociedade capitalista, impedindo as possibilidades de formação de uma individualidade rica e livre que a sociedade capitalista torna possível e, ao mesmo tempo, impede.

Nessa perspectiva, a alternativa ontológica de Lukács (Oldrine et al., 2002, p. 74), para além dos conflitos de classes e das contradições presentes na sociabilidade capitalista de produção, passa a ilumi- nar outros momentos igualmente importantes no desenvolvimento do gênero humano: permanecer no gênero em-si, submisso à manipulação capitalista e ao estranhamento que separa os indivíduos de toda apropriação subjetiva das capacidades acumuladas no desenvolvimento das forças produtivas, ou responder ao desafio de sua presente situação ontológica, produzindo posições teleológicas que se contraponham às situações de exploração, impulsionando o desenvolvimento da humanidade.

Nesse sentido, a ontologia de Lukács tem como horizonte uma ética (Tosel, 2001, p. 162), em que o "dever-ser livre" (é) pode ser uma alternativa real, determinada, como um "poder-ser" liberado a partir da esfera do "ser precisamente-assim-existente" da sociabilidade capitalista. Nesse contexto, a luta pela liberdade humana incorpora momentos de escolhas, entre as opções existentes, daquelas ações que apontam para um devir humano autêntico e que, portanto, se constitui base da construção da generalidade humana para-si.

Quanto à real possibilidade de objetivação do ser para-si na sociabilidade capitalista, Lukács sinaliza a exigência de superação dos estranhamentos. Entretanto, destaca que o desenvolvimento social anima um ser cada vez mais integrado e, por isso, crescentemente portador de necessidades genéricas (Lukács, 1981, v.II**, p. 49 e 328-331); implica-se daí uma consciência progressivamente mais sintonizada com as necessidades humanas como um todo. Tal superação, entretanto, ainda irá demandar a escolhas, em escala social, de valores (idem, p. 327-328) que sejam expressão do próprio fim do desenvolvimento social: a produção de seres livres e autônomos.

Nesse contexto, as ações éticas ${ }^{4}$ ocupam, entre

${ }^{4}$ Segundo Tertulian (1991, p. 95), as notas sobre a ética de Lukács indicam seu grande interesse pelos conceitos da ética antiga, os quais designam justamente a ultrapassagem da dispersão de sentimentos e de paixões humanas em direção a um possível equilíbrio harmonioso da personalidade: a ataraxia epicurista, a sabedoria dos estóicos, a tese de Aristóteles etc. 
as considerações de Lukács, um lugar de destaque como um dos canais de potencialização das possibilidades de liberdade. Caracterizam um modo de ser (Lukács, 1981, v.II**, p. 127) pelo qual o indivíduo se libera da pura singularidade, através de um domínio efetivo sobre seus próprios afetos e paixões, e, simultaneamente, igual domínio sobre as circunstâncias exteriores. Para Lukács (Lessa, 1997, p. 131), apenas a ética se faz mediação na superação da dicotomia existente no capitalismo entre indivíduo e sociedade.

A individualidade é uma categoria social e, por isso, sua explicação não se contrapõe antinomicamente à sociabilidade, antes exige uma interação cada vez mais intensa entre a totalidade social e o indivíduo singular [...] Essa exigência no seu patamar mais elevado é a ética; é esta que ata os fios entre o gênero humano e o indivíduo que supera sua própria particularidade. (Lukács, 1981, v. II** , p. 328)

As formações sociais anteriores - escravismo, feudalismo -, nas suas linhas gerais de desenvolvimento, ofereciam aos homens, do ponto de vista ontológico, visões de mundo (Weltanschaung) permeadas de explicações transcendentes e teocêntricas. A formação capitalista ganha importância ontológica para Lukács, porque pela primeira vez os homens passam a ter consciência de que a história é um produto de suas ações, embora as decisões humanas ocorram sempre no interior de um complexo social concreto, no qual se fazem operantes forças naturais e sociais. Isso quer dizer que apenas no interior de uma malha de determinações concretas a liberdade pode efetivar-se pela práxis humana. Nesse particular, é tarefa específica da esfera da ética (Lukács, 1981, v. II*, p. 104) ser canal das necessidades humanas de liberdade.

$\mathrm{Na}$ mesma direção, destacamos que também constitui função essencial da educação, como categoria ontológica, em sua relação com a ética, ser mediação, ou participar ativamente da consubstanciação da generalidade humana para-si. Na medida em que a reprodução social, segundo as explicações de Lukács (1981, v. II*, p. 108), passa, progressivamente, a requerer mediações sociais que tornem re- conhecíveis, em escala social, as necessidades sociogenéricas postas pelo desenvolvimento social, ressaltamos que é justamente a partir dessa base ontológica que se desencadeia o desenvolvimento da educação como mediação social (complexo pertencente à totalidade social).

A educação, nessa perspectiva, é uma categoria específica do ser social: só o homem pode ser educado (Lukács, 1981, v. II*, p. 152) e, como tal, passa a se constituir complexo integrante e não alienável do devir-homem dos homens. Nesse quesito, podemos ainda destacar que a práxis educativa inaugura um processo especial de relação do indivíduo com a totalidade, na atualização das possibilidades de efetivação da liberdade. Pontuamos que a práxis educativa, entretanto, só assume sua função social mais radical e mais autêntica quando passa a se efetivar como mediação das ações de natureza ética, ou seja, quando se realiza na sociedade capitalista, possibilitando a superação da relação dicotômica existente entre indivíduos e sociedade; e também quando facilita e generaliza o entendimento de que os homens são os sujeitos de sua história, ainda que em circunstâncias não escolhidas por eles (idem, p. 304-325).

\section{Trabalho: unidade originária da relação entre ética e ontologia}

Lukács recorre à metáfora do trabalho (Franco, 1986, p. 138) para explicitar seu papel fundamental na constituição dos demais complexos sociais e, sobretudo, na constituição do complexo da ética, concebida como modalidade de práxis social sui generis, de fundamental importância no desenvolvimento do gênero humano.

O autor concebe o trabalho como forma originária (Urform) e como modelo (Vorbild) de toda práxis humana, portanto, como fundamento da ontologia e da ética. A interpretação do trabalho como metáfora em Lukács (Preve, 1985) resguarda ainda o problema da relação do sujeito com o objeto (télos e objetividade) e da relação de reciprocidade existente entre necessidade e liberdade: relação essencial no agir ético. 
Lukács realçou a diferença entre a práxis laborativa e a práxis social. O trabalho, como Urform, indica a impossibilidade de supressão da relação entre ser social e natureza orgânica e inorgânica, o que caracteriza uma concepção unitária de homem (ser biológico e ser espiritual). Nesse contexto, o trabalho constitui momento determinante da reprodução do ser social no seu complexo. E, ao mesmo tempo, indica o salto ontológico do gênero mudo da natureza (animais) para o ser social, iniciando o processo de autocriação humana (base genética do surgimento dos valores sociais) no desenvolvimento de um mundo cada vez mais social (afastamento das barreiras naturais), paralelo à conversão progressiva da natureza em produtos sociais.

O trabalho, como Vorbild, constitui o modelo de toda práxis social, porque a relação entre teleologia e causalidade, ${ }^{5}$ que é específica do trabalho, é também atuante em outros campos da práxis humana. Lukács destaca mesmo que, "entre o modelo e sua variante sucessiva, muito mais complexa, existe uma relação de identidade e não identidade" (Lukács, 1981, v. I, p. 76); isso é: a práxis social tem, na estrutura do trabalho, seu modelo (e base genética), mas não se confunde com ele.

Diferentemente do caso do ato laborativo, na práxis social os resultados das intenções humanas (télos) acarretam conseqüências muito mais imprevisíveis, ou seja: entre o fim projetado pelo sujeito e as causalidades por ele postas em movimento intervem uma mistura muito maior de incertezas do que as que aparecem no trabalho, porque na práxis social o sujeito de uma dada projeção jamais tem condições de controlar todos os desdobramentos de suas ações; o resultado final pode aparecer até mesmo contrário às intenções originais do sujeito, pois esse resultado sempre depende (se... então) de circunstâncias (histórico-sociais, econômicas, naturais etc.) que prevalecem sobre as intenções individuais.

${ }^{5}$ Estrutura categorial de toda práxis humana: teleologia, fim, projeção humana e a causalidade, a própria objetividade natural e social.
Nesse quadro, o indivíduo, de que a ética se ocupa em primeiro plano, também deve ser sempre analisado levando-se em conta a estrutura ontológica do ser social. Segundo Lukács, o ser social é composto por dois pólos: o indivíduo e a sociedade, existindo em indissolúvel relação de interdependência e de reciprocidade.

Na relação entre o indivíduo e a sociedade se expressam duas categorias fundamentais na compreensão da ética: a alienação e a objetivação. O interrelacionamento da alienação com a objetivação - relação desencadeada somente a partir do trabalho - por um lado esclarece a presença do novo (produtos sociais inexistentes na natureza) e o resultado do empenho humano no domínio sobre as determinações objetivas do real; e, por outro, traduz a forma de expressão da individualidade humana sobre a objetividade social. Por isso, o trabalho é concebido como esfera ontológica originária da capacidade humana de exprimir-se sobre a objetividade.

Assim sendo, em Lukács é com base na estrutura ontológica do trabalho que se pode esclarecer a gênese da liberdade (as escolhas do sujeito entre alternativas no ato de trabalho), cuja estrutura básica permanece presente, também, na ética: os homens, através das escolhas alternativas, podem decidir-se por valores genéricos que impulsionam o desenvolvimento do gênero humano. Nesse sentido, a esfera da ética é mediação de uma consciência que se afirma não como simples epifenômeno das determinações objetivas, mas, sobretudo, como possibilidade ativa de escolhas/decisões que traduzem autodomínio humano, tanto das circunstâncias interiores, subjetivas, quanto das circunstâncias objetivas.

No entanto, para o autor, a questão a esclarecer, no campo da ética, diz respeito à relação aparentemente contraditória entre a realização de uma subjetividade histórica e socialmente condicionada e a realização de uma individualidade capaz de escolher, entre os valores em luta, aqueles que são capazes de uma elevação ao para-si do gênero humano. Os valores de liberdade também englobam uma multiplicidade de significados, com avanços e refluxos no seu sentido, no decorrer do desenvolvimento social. 
O importante, para Lukács, é a compreensão de que a noção de liberdade é sempre herdada pelos limites da vida em sociedade e, embora as possibilidades para sua efetivação real no interior da sociabilidade capitalista dependam da superação de todo tipo de exploração, e que seu sentido mais elevado possa ser obscurecido, esse campo pode sempre ser ampliado e atualizado pela práxis humana. Decorre dessa afirmação que, mesmo na sociabilidade burguesa, a ética só pode encontrar seu fundamento na imanência do próprio processo do fazer-se homem, implicando a busca de afirmação de um ser livre e, por isso, de uma dimensão fundamental da atividade humana. Para Lukács, o valor ético é, assim, um produto do próprio devir-humano, ou do próprio sentido de todo desenvolvimento social.

Segundo Lukács, a individualidade humana é formada através de uma crescente conscientização de pertença ao gênero humano, de uma consciência que se esforça constantemente para realizar o seu ser "para-si". A forma de realização deste "para-si" individual é, contudo, progressivamente diversificada, originada da socialização progressiva do ser social e da dinâmica própria do processo social. Nesse particular, toda determinação real da personalidade, tanto em sua riqueza como em suas formas estranhadas, surge da realização prática do ser com seu ambiente social, das relações sociais com os outros indivíduos e do intercâmbio orgânico com a natureza; enfim, a individualidade se efetiva no complexo do ser social, no mesmo processo em que a totalidade social se articula concretamente.

Se a dimensão ética está contida no próprio processo de fazer-se homem, na conquista progressiva da liberdade, ela constitui, nesses termos, esfera fundamental da práxis social em sua totalidade, que demanda grande responsabilidade do indivíduo na escolha entre os valores em luta. Dependendo das escolhas humanas, pode-se contribuir para a conservação das situações de exploração do homem sobre o homem, ou para uma transformação de determinada configuração histórica.

A esfera da ética também abrange um pólo indi- vidual e um pólo social. Somente na perspectiva de atuação nesses dois pólos, individual e pessoal, abrese uma real possibilidade de realização de uma personalidade livre e autêntica ou da efetivação da "generidade para-si”. Nesse processo, a ética ${ }^{6}$ tem papel essencial na síntese e generalização, em escala social, dos valores (social e individual) que expressam as necessidades humano-genéricas de liberdade.

Nesse particular, a concepção lukacsiana de ética refuta uma compreensão tanto de indivíduo isolado da sociedade quanto de indivíduo como mero produto mecânico do movimento econômico; essa concepção não comporta tampouco uma concepção apriorística e teleológica de história.

\section{A relação ética, ontologia e educação}

De acordo com Lukács (1981, v. II*), o complexo da educação caracteriza um conjunto de atividades ou uma relação entre o sujeito e a objetividade que perdura pela vida toda, do nascimento até a morte. A práxis educativa pode ser caracterizada como um tipo sui generis, que somente pode ser apreendida por meio de uma análise de suas origens e de seu desenvolvimento como complexo (categoria) do ser social.

Faz-se necessário ressaltar que a educação apresenta, na sociedade, uma perspectiva ampla (em um sentido lato, a educação em geral, não escolar) e uma perspectiva restrita (a educação formal, escolar, por iniciativa de instituições específicas ou de igrejas, sindicatos etc.).

Com o fim de delimitar o campo a partir do qual serão feitas as análises sobre a gênese e o papel do complexo social da educação no desenvolvimento do gênero humano, no presente texto a categoria "edu-

\footnotetext{
${ }^{6}$ Segundo Vitória Franco (1986, p. 148-149), a relação en-
} tre ética e ideologia tem relevante papel na interação entre o social e o individual, articulando visão de mundo e conduta prática, através de escolha, decisão humana, que reconhece, como próprio dever, deveres que expressam as necessidades humano-genéricas. 
cação" será tratada em seu sentido lato e será definida como atividade necessária a todo processo de objetivação, apropriação e reprodução do indivíduo enquanto gênero. Isso não significa, contudo, que, ao se buscar a essência ontológica da educação em sua dimensão ampla, se está pressupondo sua existência fora da história. Em Lukács, é impossível a apreensão de qualquer categoria social fora da história dos homens.

Nas análises sobre a educação será adotada a perspectiva ético-ontológica de Lukács, que parte da compreensão de que os homens são os únicos sujeitos responsáveis por sua história - portanto, que apenas eles são capazes de atualização das possibilidades de sua própria emancipação. Para tal, na real apreensão do papel da práxis educativa no desenvolvimento do gênero humano tem-se, necessariamente, que buscar apoio na afirmação lukacsiana da prioridade ontológica da realidade (objetividade) - a única instância capaz de engendrar as reais condições da passagem do gênero em-si para o gênero para-si -, bem como a atualização na consciência das possibilidades que caracterizam tal passagem.

Se na Ontologia de Lukács se encontram os fundamentos capazes de esclarecer a especificidade de atuação dos complexos sociais no desenvolvimento do ser social é, entretanto, no campo da ética que se viabiliza a apreensão da função social da práxis educativa em sua radicalidade, como atividade imprescindível ao desenvolvimento do gênero humano.

\section{Considerações ontogenéticas sobre o desenvolvimento do complexo social da educação}

A afirmação segundo a qual a educação remonta às origens do próprio homem, em resposta às suas necessidades, constitui uma completa abstração, se não se reconstituem os reais fundamentos sobre os quais se apóia essa afirmação.

Nessa perspectiva, as análises que seguem serão apoiadas nas considerações ontogenéticas de Lukács. As questões sobre o complexo da educação fundam- se sobre a tese cardeal do autor em foco: as manifestações humanas implicam, sempre, uma proporcionalidade direta entre a subjetividade humana e o seu enraízamento no mundo objetivo (Tertulian, 1980, p. 188).

Lukács afirma, sobretudo no capítulo sobre o trabalho de sua Ontologia (1981), que cada manifestação da subjetividade humana se encontra condicionada de múltiplas maneiras pelas suas relações com a realidade objetiva. Então, por mais elementar que seja uma atividade humana, ela surge sempre como resposta aos problemas que ocorrem no curso do processo de produção e reprodução da existência; a atividade, ela mesma, na maioria das vezes só se pode efetivar quando há, por parte do sujeito, uma observação atenta das propriedades causais objetivas da realidade - e ainda que a repetição de determinadas ações prescinda dessa obrigatoriedade.

Assim, através de suas atividades teleológicas, o homem torna-se um ser sempre capaz de interromper as séries causais naturais e introduzir, no determinismo natural, uma nova ordem: ele submete o movimento da matéria às suas intenções; todavia, para materializar realmente seus desejos, o homem deve sempre se apoiar sobre um conhecimento, o mais aproximativo possível, a respeito dos objetos existentes no seu campo de ação.

$\mathrm{O}$ autor ainda ressalta a resistência objetiva, posta pela densidade e opacidade do real, às iniciativas humanas. Nessa questão, a relação teleologia/causalidade presente no processo de trabalho passa a lançar luzes sobre como ocorre tal resistência às intenções humanas; assim, para uma compreensão de qualquer outro nível de atividade humana, há que se pressupor a centralidade da categoria trabalho como modelo paradigmático.

Sempre, segundo Lukács, se faz necessário ter como pressuposto o fato de que baseado no trabalho, pela primeira vez, se estabelece uma verdadeira relação sujeito-objeto. Não somente um objeto em face de um sujeito, mas também um sujeito autônomo defronte à objetividade. A autoconstrução da subjetividade e o desenvolvimento progressivo das capacida- 
des humanas estão em relação direta com os atos humanos de manipulação e de dominação da realidade objetiva. Pode-se com isso afirmar que cada uma das propriedades da subjetividade humana está sempre marcada pela antecedência de atos práticos que lhe deram origem.

As explicações ontológicas do autor nos indicam que o complexo social da educação é constituído como uma das capacidades subjetivas do homem, nascida no curso do processo de produção e de reprodução da sociedade. Surge, para o ser social, como um caso específico de relação sujeito-objeto e, por que não dizer, como uma forma social evoluída e particularmente modificada da relação primária sujeito-objeto, originada pelo ato de trabalho.

Apesar de tais esclarecimentos, permanece ainda obscura a questão inicial: Qual é a origem do complexo social da educação?

Em primeiro lugar, pode-se afirmar que o complexo social da educação tem a mesma base ontológica que serve ao aparecimento das demais expressões espirituais humanas - isso é, ele aparece como expressão das capacidades humanas e da necessidade de domínio sobre a realidade, surgidas em uma certa etapa do desenvolvimento histórico-social. Entretanto, em virtude da dificuldade de se fornecerem explicações precisas sobre como e quando o complexo social da educação se diferencia, progressivamente, de outras atividades espirituais, as afirmações de Lukács prolongam os pressupostos já afirmados em sua Ontologia: a práxis educativa do homem foi precedida de um longo devir histórico e houve, certamente, uma "pré-história" de sua aparição, bem como uma estratificação progressiva de suas qualidades constitutivas, até suas formas evoluídas (ad quem), já cristalizadas, existindo de forma autônoma na sociabilidade.

No caso dessa ontogênese, portanto, deve-se procurar as linhas gerais de seu desenvolvimento no tecido social no qual surgiram os momentos cruciais de avanços e de retrocessos, ou como resultado das mutações decisivas ocorridas no devir-humano dos homens, analisando o complexo social da educação como manifestação da práxis espiritual dos homens e compreendendo a práxis educativa como categoria historicamente determinada, produto da relação sujeito-objeto.

Nesse sentido, pode-se afirmar que o complexo social da educação surgiu, na vida cotidiana, como resposta à necessidade de expressão e de domínio sobre a realidade a que as formas de pensamento cotidiano não eram capazes de responder conscientemente. Em sua mistura de rigidez e maleabilidade, essas formas de pensamento misturam, assim, empirismo e explicações transcendentes.

Só quando os imperativos práticos da existência humana passam a exigir uma generalização crescente de conhecimentos adquiridos pelas ações é que se pode inferir, do ponto de vista ontológico, que a educação se apresenta como complexo social, com seus traços característicos e existindo de forma mais ou menos homogênea. Assim, estão dadas as condições para seu pleno desenvolvimento categorial. Desta mesma particularidade também se origina a gênese da ciência - embora esta última se desenvolva com base em um sistema de conhecimentos predominantemente mais autônomo e homogêneo.

De tais considerações se conclui que, a partir de sua origem, o complexo social da educação assumiu uma função específica no conjunto da práxis humana, obedecendo, inicialmente, à exigência prática de atuar na generalização dos conhecimentos, bem como na sua purificação de todo traço de subjetividade, de forma que forneça à reflexão humana, da maneira mais adequada possível, tanto elementos sobre as propriedades da matéria quanto informações sobre as relações existentes entre os fenômenos.

No entanto, conforme Lukács, os acontecimentos da história desencadeiam, também, interpretações baseadas em suposições subjetivas. A magia e a religião (Tertulian, 1980, p. 196) representam exemplos privilegiados dessa "dominação" espiritual sobre a realidade, em que os elementos subjetivos e transcendentes de interpretação dos fenômenos exteriores predominam na consciência humana: imagina-se que um poder transcendente, subjetivo, decide sobre a 
divergência ou a convergência dos acontecimentos exteriores. Nesse contexto, o complexo da educação constitui-se também como um prolongamento original dessas formas subjetivas de interpretação do mundo, inauguradas pela magia e pela religião.

Em seu desenvolvimento, a educação tende para um dos pólos da relação sujeito-objeto e, como complexo do ser social, atua como mediação fundamental na busca de um equilíbrio dessa relação. Compreende-se, então, que o complexo da educação tem seu lugar no mundo, tanto na mesma linha ontogenética das origens da ciência (conhecimentos deantropormorfizantes) quanto aliado às interpretações predominantemente subjetivas, antropormorfizantes (a exemplo da magia, da religião, da arte etc.). Somente quando se estabelece uma relação dialética equilibrada entre a objetividade e a subjetividade é que o reflexo do mundo, no pensamento humano, passa a reunir condições necessárias à sua organização como esfera espiritual e, também, sob a forma de complexo social da educação, existindo como esfera categorial autônoma.

Ora, o complexo social da educação só se pode desenvolver a partir do momento em que ocorre uma certa "autonomização" de formas diferenciadas de expressão espiritual da realidade. Lukács (Tertulian, 1980, p. 199) registra o aparecimento, na Antigüidade, de um fenômeno em que a "autonomização" de diversas formas espirituais mostrou-se bastante sensível, acusando, no mesmo tecido social, a presença de uma mistura de formas indiferenciadas e intermediárias de atividades espirituais. Este fato autoriza a afirmação de que o pleno desenvolvimento da educação (não a sua origem), como complexo categorial parcial do ser social, teve na Antigüidade o seu solo histórico-social. Assim, subjetividade "antropomorfizante" e objetividade "desantropomorfizante" constituem os dois pólos que balizam o complexo da educação.

Desde essas origens, a educação tem a função social de conservar a objetividade do mundo em-si na consciência e, nesse particular, assume simultaneamente a função de ampliar as capacidades subjetivas na apreensão do real. Surge com a função de mediação na apreensão e generalização de conhecimentos sobre a realidade objetiva, sob a perspectiva de domínio sobre a realidade segundo as exigências humanas.

Paralelamente à práxis laborativa, desenvolvemse relações entre os homens, cuja substancialidade é mediatizada por objetivações de ordem espiritual, de que a práxis educativa é um dos exemplos. Esta última se movimenta por teleologias que, em sua essência, envolvem não mais o contato direto homem e natureza, mas relações intersubjetivas entre os sujeitos.

As posições teleológicas secundárias consubstanciam, então, a práxis humana espiritual e por isso se diferenciam da práxis entificadora de objetivações econômicas (práxis laborativa = posições teleológicas primárias). No caso do complexo social da educação, através da práxis pedagógica são mobilizados os seguintes elementos na efetivação das intenções humanas: teleologia, subjetividade, causalidade posta e, novamente, subjetividade.

A práxis educativa realiza-se por meio de uma circularidade de movimento entre o sujeito, o objeto e novamente o sujeito; entre o conhecimento de si e o conhecimento do mundo. Por essa base, torna-se possível um equilíbrio entre a subjetividade e a objetividade, ou seja: as relações da subjetividade, na práxis educativa, em contato com a objetividade, obtêm como termo final um crescente enriquecimento da subjetividade.

Assim, a educação constitui, precisamente, um nível mais espiritual e consciente do próprio processo de trabalho, surgindo ligada ao comportamento humano de auscultação da matéria, presente em todo ato de trabalho. No trabalho, existe uma relação prática e direta entre o sujeito e a realidade objetiva; na educação, a relação homem-natureza é mediatizada, envolvendo, prioritariamente, relações intersubjetivas, visando à apropriação, pelo sujeito, das diversas formas de objetivação humana (material, social, espiritual) e tendendo a fixar a relação do homem com a realidade na forma de conhecimentos generalizados indispensáveis às futuras objetivações.

Então, baseado em uma posição teleológica primária que caracteriza o trabalho (relação homem-na- 
tureza) desencadeiam-se outros tipos de posições teleológicas. Destacam-se, aqui, as posições teleológicas secundárias, ou aquelas que, em vez de buscar diretamente a transformação da natureza, têm por objetivo influenciar na escolha das alternativas a serem adotadas por outros indivíduos, visando convencêlos a agir numa determinada direção.

No caso da práxis educativa (teleologia secundária: relação homem-homem), o princípio ontológico presente na estrutura do trabalho também permanece válido: nenhum empreendimento humano tem chance de êxito se não leva em conta as séries causais objetivas. Mas, na dinâmica operante na práxis educativa, a obrigatoriedade do contato com a realidade objetiva farse-á mediada pela subjetividade. Aqui o sujeito se constitui o próprio telos da práxis educativa.

\section{A dimensão ética da educação}

O complexo social da educação realiza-se pela mediação da práxis educativa, por meio das apropriações das capacidades humanas e pelas incorporações, por parte dos sujeitos, dos produtos sociais que constituem patrimônio histórico da humanidade (trabalho, estética, ética etc.).

Nessa condição, utilizando a própria expressão de Lukács (1981, v. II*, p. 152), a educação diz respeito àquele conjunto de atividades humanas presentes nos confrontos dos sujeitos entre si e destes com a objetividade.

De um ponto de vista ontológico, a educação traduz uma relação entre sujeitos, e destes com a materialidade social, e sempre se situa num dado contexto sócio-histórico, numa relação de condicionamento recíproco. Contudo, em cada momento histórico-social, assume funções sociais específicas. A crescente "complexificação" do ser social e a divisão da sociedade em classes passa a exigir a criação de um setor separado para se ocupar da direção do processo de apropriação dos conhecimentos, que, em grande parte, é espontaneamente garantido pelas relações educativas sociais travadas entre os sujeitos. Constitui-se, assim, o campo particular da educação (a escola, por exemplo), que, na sociedade capitalista, é controlado, feito instrumento de execução de uma posição teleológica social, subordinada à valorização do capital. Em outras palavras, o complexo social da educação passa a ser controlado segundo a realidade da divisão do trabalho, das forças produtivas, das relações sociais e das formas de estranhamento (Enfremdungen) existentes. Essa situação, no entanto, não impede que o sujeito, ao se apropriar (no sentido amplo de educação) de conhecimentos, possa exercer certo controle sobre as causalidades (objetividade) e venha a realizar ações e objetivações, não apenas no sentido da reprodução de sua situação histórica particular, mas também no sentido de atualização das possibilidades de transformação social.

Esse fato confirma não somente a tese de que, ontologicamente, os resultados da educação sempre são incertos, mas também de que a educação do homem é um continuum, jamais totalmente concluído, mediatizando sempre a abertura de novos campos às ações humanas nas escolhas dos sujeitos. Como parte do complexo unitário do ser social, a educação desenvolve-se em meio às mesmas contradições presentes na sociedade.

Os conhecimentos, os valores, a cultura são continuamente transmitidos na e pela práxis educativa; isto, entretanto, sempre ocorre de modo desigual, com base em um processo de reprodução social também desigual, que implica a incorporação, pela consciência social, de elementos do passado, do presente e do futuro pertencentes ao movimento, igualmente contraditório, do real.

Na relação da educação com a totalidade social, fundem-se, por relações contraditórias e de reciprocidade, elementos particulares, referentes a uma dada configuração histórico-social, tanto quanto se incorporam elementos genéricos que concernem ao desenvolvimento da sociedade como um todo. Concluise, portanto, que a educação é uma categoria portadora tanto de elementos genéricos, quanto de elementos particulares.

Tendo por base as considerações ontológicas de Lukács, pode-se então afirmar que embora a educa- 
ção, como complexo de atividades que faz parte da totalidade do ser social, não possua por si só a capacidade de provocar uma ruptura com um determinado modo de produção, isso em nada diminui seu papel fundamental no desenvolvimento do gênero humano: existe uma ineliminável dimensão ética na práxis educativa que, concebida no seu sentido ontológico originário de estar a serviço da satisfação das necessidades humanas, é importante mediação nas decisões e nas ações do sujeito na luta e na conquista da liberdade.

Embora o capitalismo ${ }^{7}$ reproduza, predominantemente, momentos de negação da liberdade, não se pode afirmar que essas limitações se referem a uma negação total dessa possibilidade, na transcendência positiva das hierarquias sociais existentes. Se, de um ponto de vista ontológico, pode-se afirmar que o homem é um eterno construir-se a partir da totalidade que o cerca, pode-se também afirmar que sua entificação com ser livre não se encontra desde sempre estabelecida. Essa determinação é tarefa da práxis humana e, portanto, também da educação. Em outras palavras, a indeterminação no existir humano também significa um dever-ser a ser efetivado no curso da história.

Todas as vezes que a educação, situada no conjunto da práxis humana, é capaz de fornecer ao homem um quadro referencial básico, a partir do qual ele se possa situar ao agir no mundo na conquista pela liberdade, ela se realiza como atividade própria do "fazer-se homem do homem" e passa a assumir sua radi-

${ }^{7}$ Ocorre nas condições do capitalismo: “A objetivação em condições nas quais o trabalho se torna exterior ao homem assume a forma de um poder estranho que enfrenta o homem de uma maneira hostil. Esse poder exterior, a propriedade privada, é o produto, o resultado, a conseqüência necessária, do trabalho alienado, da relação exterior entre o trabalhador e a natureza, entre o trabalhador e ele próprio. Assim, se o resultado desse tipo de objetivação é a produção de um poder hostil, então o homem não pode contemplar-se num mundo por ele criado, mas sujeitando-se a um poder exterior e privado de sentido [...], e com isso restringe ainda mais a sua própria liberdade" (Mészáros, 1981, p. 141). calidade ética. A apropriação do conhecimento de um dado contexto histórico-social, em suas dimensões particulares e universais, é ressaltada aqui como prérequisito na apropriação/reprodução daquelas objetivações portadoras do gênero humano para-si.

MÔNICA MOTA TASSIGNY, doutora em educação pela Universidade Federal do Ceará e pelo E.H.E.S.S (École des Hautes Études en Sciences Sociales) de Paris, é professora do Centro de Ciências Humanas da Universidade de Fortaleza (UNIFOR). Publicou: A categoria trabalho como princípio educativo e o debate educacional sobre a relação trabalho e educação. In: ARRAIS NETO, Enéas, Manuel J. P., FELISMINO, Sandra C. (org.). A crise do mundo do trabalho no capitalismo global. Cadernos de Pós-Graduação Brasileira, Fortaleza: UFC, v. 4, p. 155-166, 2002 (coleção Diálogos Intempestivos); O debate sobre a centralidade do trabalho: que trabalho e qual centralidade? In: XV Encontro de Pesquisa Educacional das Regiões Norte e Nordeste, Anais. São Luís, 2001. Apresentou: Le fondament ontologique de la relation travail-education. In: Congress Marx International. Paris: Sorbonne, 2001. E-mail: monicam@secrel.com.br

\section{Referências bibliográficas}

FRANCO, V., (1986). Ética e ontologia in Lukács. Crítica Marxista, $\mathrm{n}^{\circ}$ 4, Roma, ano 24, p. 134-150.

KOEFLER, L., HOLZ, Abendroth, (1969). Conversando com Lukács. Rio de Janeiro: Paz e Terra.

LESSA, Sérgio, (1997). A ontologia de Lukács. 2a ed. Maceió: EDUFAL.

LUKÁCS, Georg, (1967). Estética - v. 3. Barcelona/México: Garijalbo.

, (1979). Os princípios ontológicos fundamentais de Marx. São Paulo: Ciências Humanas, 1979.

, (1981). Per uma ontologia dell'essere sociale v. I, II* e II**. Roma: Riuniti. Tradução de Alberto Scarponi. (1990). Prolegomini all'ontologia dell'essere sociale. Milão: Guerini e Associati.

MÉSZÁROS, István, (1981). Marx : a teoria da alienação. Rio de Janeiro: Zahar.

OLDRINE, G., LESSA, S., PINASI, M. (orgs.), (2002). Em busca das raízes da ontologia (marxista) de Lukács. In: Lukács e a atualidade do marxismo. São Paulo: Boitempo. 
PREVE, C. , (1985). Textes de G. Lukács. Paris: Éditions Sociales/ Messidor.

TERTULIAN, N., (1971). L'évolution de la pensée de Georg Lukács. L'homme et la société. Revue Internationale de Recherches et de Synthéses Sociologiques, Paris, Éditions Antropos, no 20, p. 13-36.

, (1979). Georg Lukács et la reconstruction de l'ontologie dans la philosophie contemporaine. Revue de Métaphysique et de la Morale, Paris, Société Française de Philosophie, s/no, p. 301-317.

, (1980). Georg Lukács, étapes de sa pensée esthétique.

Paris: Le Sincomore.
, (1984). L'Ontologie de Georg Lukács. Bulletim de la Societé Française de Philosophie, no 4, p. 129-174, out.-nov. , (1991). Le grand projet de l'éthique. Actuel Marx, $\mathrm{n}^{\mathrm{o}} 10$, p. $81-96$. , (1999). La pensée du dernier Lukács. Critique, $\mathrm{n}^{\circ}$ 517-518, p. 594-616, juin.-juillet.

TOSEL, A., (2001). Le dernier Lukács et l'école de Budapest. In: Dictionnaire Marx contemporain. Paris: Presses Universitaires de France.

Recebido em março de 2003 Aprovado em agosto de 2003 